\title{
Peningkatan Kemampuan Berpikir Kritis Matematis Siswa SMA Melalui SQ3R
}

\author{
Runisah \\ Universitas Wiralodra; Jl. Ir. H. Djuanda Km 3 Indramayu, Indonesia; \\ runisah@unwir.ac.id.
}

\begin{abstract}
Abstrak
Penelitian ini bertujuan untuk mengkaji peningkatan kemampuan berpikir kritis matematis siswa yang mengggunakan SQ3R. Penelitian ini merupakan penelitian kuasi eksperimen yang melibatkan 72 siswa kelas $X$ dari salah satu SMA di Indramayu, Jawa Barat. Data dianalisis menggunakan uji $t^{\prime}$, Anova Satu jalur dan uji Scheffe. Dari hasil penelitian disimpulkan bahwa: 1) Peningkatan kemampuan berpikir kritis matematis siswa yang pembelajarannya menggunakan SQ3R lebih baik dari siswa yang menggunakan pembelajaran konvensional; 2) Peningkatan kemampuan berpikir kritis matematis siswa yang mengunakan SQ3R dengan kemampuan awal tinggi lebih baik dari siswa dengan kemampuana awal sedang, dan peningkatan kemampuan berpikir kritis matematis siswa berkemampuan awal sedang lebih baik dari siswa berkemampuan awal rendah.
\end{abstract}

Kata kunci. berpikir kritis, matematika, SQ3R

\begin{abstract}
This study aims to examine the improvement of mathematical critical thinking skills of students who had learned using SQ3R. This research was quasi-experimental study involving 72 ten grade students from one of the high schools in Indramayu, West Java. Data were analyzed using t-test, One-way Anova and Scheffe test. The study concluded that: 1) the improvement of student's mathematical critical thinking skills who had learned using SQ3R was better than the improvement of student's mathematical critical thinking skills who had learned using conventional model. 2) the improvement of student's mathematical critical thinking skills who had learned using SQ3R with high prior ability is better than student's mathematical critical thinking skills with moderate prior ability, and the the improvement of student's mathematical critical thinking skills with moderate prior ability is better than student's mathematical critical thinking skills with low prior ability
\end{abstract}

Keywords. Critical thinking, mathematics, SQ3R

Euclid, p-ISSN 2355-1712, e-ISSN 2541-4453, Vol. 6, No. 2, pp. 145- 156

(CLembaga Penelitian Universitas Swadaya Gunung Jati (UGJ), Cirebon. 


\section{Pendahuluan}

Berpikir reflektif dan beralasan yang difokuskan pada pengambilan keputusan tentang apa yang harus diyakini atau dikerjakan merupakan pengertian berpikir kritis yang dikemukakan Ennis (1996). Selanjutnya Eggen \& Kauchak (2012) menjelaskan bahwa berpikir kritis merupakan kemampuan dan kecenderungan untuk membuat dan melakukan penilaian terhadap kesimpulan berdasarkan bukti. Sementara itu terkait dengan matematika, menurut Glazer (2001) berpikir kritis dalam matematika adalah kemampuan dan disposisi untuk melibatkan pengetahuan awal, penalaran matematis, dan strategi kognitif secara reflektif untuk membuat suatu generalisasi, menyusun bukti, atau melakukan penilaian terhadap suatu situasi matematis yang tidak rutin. Dengan demikian kemampuan berpikir kritis diperlukan dalam mengambil keputusan atau dalam menyelesaikan permasalahan.

Namun demikian, beberapa studi menunjukan kemampuan berpikir kritis siswa masih rendah. Hasil The Trends in International Mathematics and Science Study (TIMSS) menujukan bahwa sejak tahun 1999 hingga tahun 2015 Indonesia berada pada peringkat bawah (Nizam, 2016; Mullis \& Martin, 2013). Penelitian tersebut dilakukan pada siswa sekolah menengah pertama dan sekolah dasar. Selanjutnya dari hasil studi pada siswa SMA di Kabupaten Indramayu, Runisah (2012) menyimpulkan bahwa kemampuan berpikir kritis matematis siswa masih rendah. Oleh karena itu diperlukan strategi yang dapat memfasilitasi siswa untuk mengembangkan kemampuan berpikir kritis.

Salah satu strategi yang memacu siswa untuk berpikir kritis yaitu SQ3R. SQ3R terdiri dari tahap survey, question, read, recite, review, Pada tahap survey siswa melakukan penyelidikan/kaji awal (survey) terhadap bahan bacaan secara cepat (pengenalan terhadap kalimat, judul bacaan, dll). Pada tahap question siswa membuat pertanyaan berkaitan dengan bacaan. Pada tahap read, siswa membaca ulang untuk menjawab pertanyaan pada langkah sebelumnya. Pada tahap recite, siswa menjawab pertanyaan pada langkah sebelumnya. Pada tahap review, siswa mengkaji ulang jawaban yang telah diberikan serta keseluruhan materi secara detail. 
Penggunaan SQ3R melibatkan siswa untuk belajar secara aktif dalam membangun pengetahuan berkaitan dengan materi yang diajarkan. Dengan demikian SQ3R merupakan strategi yang berbasis konstruktivisme. Piaget (Dahar, 1989) sebagai konstruktivis pertama menjelaskan bahwa pengetahuan fisik dan logika matematika tidak dapat secara utuh dipindahkan dari pikiran guru ke siswa, namun siswa membangun sendiri pengetahuan-pengetahuan tersebut.

Banyak penelitian yang telah dilakukan oleh para peneliti untuk mengembangkan kemampuan berpikir kritis matematis siswa. Diantaranya penelitian yang dilakukan oleh Kurniati, Kusumah, Sabandar \& Herman (2015) dan Firdaus, Kailani, Nor \& Bakry (2015), masing masing menggunakan pembelajaran kontekstual dan PBL. Kedua pembelajaran berbasis konstruktivisme tersebut efektif untuk mengembangkan kemampuan berpikir kritis matematis siswa.

Sementara itu penelitian tentang penggunaan SQ3R dalam pembelajaran matematika masih terbatas. Beberapa penelitian terkait dengan penggunaan SQ3R diantaranya dilakukan oleh Pujawan (2005). Pujawan (2005) menyimpulkan bahwa penerapan model pembelajaran kooperatif SQ3R meningkatkan aktivitas dan prestasi belajar siswa. Selanjutnya Firmansyah, Zaenuri \& Mulyono (2012) menyimpulkan bahwa model pembelajaran kooperatif tipe SQ3R efektif untuk meningkatkan kemampuan pemecahan masalah siswa kelas VII pada materi pokok hubungan antar sudut. Selanjutnya, Subekti dan Yanuarto (2013) menyimpulkan adanya peningkatan cara berkomunikasi belajar matematika mahasiswa melalui penggunaan SQ3R.

Selain pemilihan strategi pembelajaran yang sesuai, faktor lain yang turut mempengaruhi kemampuan berpikir kritis siswa yaitu kemampuan atau pengetahuan awal siswa. Hal ini sejalan dengan pendapat Glazer (2011) sebagaimana telah diungkapkan sebelumnya bahwa selain penalaran matematis dan strategi kognitf, pengetahuan awal dilibatkan ketika seseorang berpikir kritis matematis.

Dengan melihat penelitian penggunaan SQ3R yang masih terbatas, penulis menganggap perlu untuk mengkaji tentang pengaruh penggunaan SQ3R 
terhadap peningkatan kemampuan berpikir kritis matematis siswa. Secara lebih rinci penelitian ini bertujuan untuk:

1. Mengkaji perbedaan peningkatan kemampuan berpikir matematis antara siswa yang menggunakan SQ3R dengan yang menggunakan pembelajaran konvensional

2. Mengkaji peningkatan kemampuan berpikir matematis siswa yang menggunakan SQ3R berdasarkan kemampuan awal siswa (tinggi, sedang, rendah)

\section{Metode Penelitian}

Penelitian ini dilaksanakan dengan menggunakan metode kuasi eksperimen, dengan desain kelompok kontrol pretes-postes. Populai merupakan siswa SMA di Kabupaten Indramayu. Dari seluruh SMA yang ada dipilih secara acak satu SMA. Dari SMA tersebut dipilih kelas $X$ sebagai sampel dengan menggunakan teknik purposive sampling. Dari siswa kelas $X$ dipilih satu kelas yang menggunakan SQ3R dan satu kelas menggunakan pembelajaran konvensional. Jumlah siswa untuk kelas eksperimen dan kontrol masingmasing 36 orang.

Selanjutnya penentuan kelompok siswa tinggi, sedang, dan rendah didasarkan pada kemampuan awal siswa. Untuk menentukan skor tes kemampuan awal matematika (KAM) siswa digunakan rata rata hasil tes siswa tersebut pada materi sebelumnya (tes sub sumatif) yang diberikan oleh guru. Adapun kriteria pengelompokan siswa yang digunakan adalah sebagai berikut:

$$
\begin{array}{r}
\mathrm{x} \geq \overline{\mathrm{x}}+\mathrm{SB}: \text { Siswa kelompok KAM tinggi } \\
\overline{\mathrm{x}}-\mathrm{SB} \leq \mathrm{x}<\overline{\mathrm{x}}+\mathrm{SB}: \text { Siswa kelompok KAM sedang } \\
\mathrm{x}<\overline{\mathrm{x}}-\mathrm{SB}: \text { Siswa kelompok KAM rendah }
\end{array}
$$

Keterangan:

$\mathrm{x}$ : skor tes KAM siswa= rata-rata skor tes sub sumatif) 
$\overline{\mathrm{x}}$ : rata rata skor tes $\mathrm{KAM}$

SB : simpangan baku

Dalam penelitian ini, pada kelas eksperimen siswa berdiskusi secara berkelompok menggunakan strategi SQ3R dengan langkah langkah sebagai berikut:

1) Pada tahap Survey siswa ditugaskan menentukan setiap konsep penting yang ada pada bacaan/naskah.

2) Pada tahap Question siswa ditugaskan membuat pertanyaan yang berkaitan dengan konsep penting yang ditemukan pada tahap survey. Dalam membuat pertanyaan, siswa diarahkan untuk membuat pertanyaan yang memerlukan jawaban berupa penjelasan yang disertai alasannya, dan pertanyaan mengenai keterkaitan antar konsep, baik keterkaitan antara konsep yang ada dalam bacaan maupun keterkaitan antara konsep yang ada pada bacaan dan konsep lain di luar bacaan.

3) Pada tahap ketiga (read) siswa ditugaskan membaca ulang bacaan/naskah pada bagian tertentu saja untuk menjawab pertanyaan yang telah dibuatnya.

4) Pada tahap keempat (recite) siswa ditugaskan menjawab pertanyaan.

5) Pada tahap kelima (review) siswa ditugaskan memeriksa jawaban yang diberikan pada tahap sebelumnya, kemudian membuat ringkasan berkaitan dengan konsep utama yang ada dalam bacaan.

Pada saat diskusi berlangsung guru bertugas sebagai fasilitator untuk memberikan bantuan apabila diperlukan. Hasil diskusi kelompok mengenai konsep konsep penting, serta pertanyaan dan jawaban yang dibuat tersebut dipresentasikan untuk mendapat tanggapan dari kelompok lain.

Penelitian ini dilaksanakan di kelas $X$ pada pokok bahasan Trigonometri. Instrumen berupa tes kemampuan berpikir kritis matematis berbentuk uraian berjumlah 7 dengan skor maksimal ideal 35. Penskoran untuk kemampuan berpikir kritis matematis menggunakan rubrik penskoran yang dimodifikasi dari Facione (1994) dan Ratnaningsih (2007: 110). Sebelum 
digunakan soal diuji coba terlebih dahulu, dari hasil uji coba diperoleh $r=$ 0,86 artinya tingkat reliabilitas tinggi. Adapun validitas setiap butir soal tergolong sedang dan baik.

Untuk mengetahui besarnya peningkatan kemampuan berpikir kritis, peneliti menganalisis data hasil tes dengan rumus gain ternormalisasikan sebagai berikut:

$$
(N) g=\frac{\text { post } \mathrm{T}-\text { preT }}{\max \mathrm{T}-\text { preT }}
$$

Keterangan :

$$
\begin{array}{ll}
(N) g & : \text { gain ternormalisasikan } \\
\text { postT } & : \text { skor postes } \\
\text { preT } & : \text { skor pretes } \\
\text { maxT } & : \text { skor maksimal }
\end{array}
$$

Kriteria Indeks Gain $(g)$ adalah:

$$
\begin{gathered}
(N) g>0,7: \text { tinggi } \\
0,3<(N) g \leq 0,7: \text { sedang } \\
(N) g \leq 0,3: \text { rendah }
\end{gathered}
$$

\begin{tabular}{|c|c|c|c|c|c|c|}
\hline \multirow[b]{2}{*}{ No. } & \multirow[b]{2}{*}{ Kelas } & & \multicolumn{3}{|c|}{ Ukuran Statistik } & \multirow{2}{*}{$\begin{array}{c}\text { Skor } \\
\text { maksimal } \\
\text { Ideal }\end{array}$} \\
\hline & & & Rerata & $\begin{array}{l}\text { Deviasi } \\
\text { Standar }\end{array}$ & Varians & \\
\hline \multirow{3}{*}{1.} & \multirow{3}{*}{ Eksperimen } & Pretes & 2,56 & 1,54 & 2,37 & \multirow{4}{*}{35} \\
\hline & & Postes & 22,17 & 4,54 & 20,6 & \\
\hline & & Gain & 0,61 & 0,13 & 0,02 & \\
\hline 2. & Kontrol & Pretes & 2,69 & 1,28 & 1,65 & \\
\hline
\end{tabular}

(Meltzer, 2002)

\section{Hasil dan Pembahasan}

Data skor rerata pretes dan postes kemampuan berpikir krits matematis siswa kelas eksperimen dan kelas kontrol disajikan pada Tabel 1

Tabel 1. Deskripsi Statistik Skor Pretes dan Postes Kemampuan Berpikir Kritis Matematis 


\begin{tabular}{cccc} 
Postes & 19,28 & 2,97 & 8,83 \\
\hline Gain & 0,52 & 0,08 & 0,01
\end{tabular}

Dari Tabel 1 terlihat bahwa rerata kemampuan berpikir kritis sebelum pembelajaran antara kedua kelompok masih rendah. Kemudian dari gain yang diperoleh baik kelas eksperimen maupun kontrol memiliki katagori gain sedang.

Selanjutnya berdasarkan perhitungan diperoleh $t^{\prime}=3,46$ dan $t_{\text {kritis }}=1,69$ sehingga $\quad t^{\prime}>t_{\text {krits }}$ dengan $\alpha=0,05$. Dengan demikian dapat disimpulkan bahwa peningkatan kemampuan berpikir kritis matematis siswa yang memperoleh pembelajaran SQ3R lebih baik daripada siswa yang memperoleh pembelajaran konvensional. Selanjutnya dari hasil perhitungan dengan $A N O V A$ satu-jalur. diperoleh $F_{\text {kritis }}=32,68>F_{\text {kritis }}=3,29$ pada taraf nyata $\alpha=0,05$. Dengan demikian disimpulkan bahwa terdapat perbedaan peningkatan kemampuan berpikir kritis matematis pada kelas eksperimen antara siswa kelompok kemampuan awal tinggi, sedang, dan rendah.

Dari hasil uji Scheffé disimpulkan bahwa peningkatan kemampuan berpikir kritis siswa dengan kemampuan awal tinggi lebih baik daripada siswa dengan kemampuan awal sedang, dan peningkatan kemampuan berpikir kritis siswa dengan kemampuan awal sedang lebih baik daripada siswa dengan kemampuan awal rendah. Deskripsi statistik data gain ternormalisasi disajikan pada Tabel berikut:

Tabel 2. Data Gain Ternormalisasi Kelas Eksperimen

\begin{tabular}{llccc}
\hline No. & $\begin{array}{l}\text { Kelompok } \\
\text { Siswa }\end{array}$ & $\begin{array}{c}\text { Rerata } \\
\text { Gain }\end{array}$ & Kategori & $\begin{array}{c}\text { Jumlah } \\
\text { Siswa }\end{array}$ \\
\hline 1. & Tinggi & 0,75 & tinggi & 10 \\
\hline 2. & Sedang & 0,61 & sedang & 16 \\
\hline 3. & Rendah & 0,46 & sedang & 10 \\
\hline
\end{tabular}

Dari Tabel 2 diperoleh bahwa terdapat perbedaan kategori rerata gain kemampuan berpikir kritis antara kelompok tinggi dan sedang, antara kelompok tinggi dan rendah, sedangkan antara kelompok sedang dan rendah tidak terdapat perbedaan kategori rerata gain. Dengan memperhatikan kategori dari ketiga kelompok siswa tersebut terlihat bahwa 
penggunaan SQ3R dapat meningkatkan kemampuan berpikir kritis untuk siswa kelompok tinggi, sedang, dan rendah dengan kategori peningkatan terbesar ada pada siswa kelompok tinggi.

Hasil penelitian menunjukan bahwa kemampuan berpikir kritis matematis dapat ditingkatkan dengan menggunakan SQ3R. hal ini dimungkinkan karena berbagai kelebihan dari strategi SQ3R. Menurut Suderajat (2001) SQ3R memacu pembaca lebih aktif, kritis, sistematis, dan bertujuan dalam menghadapi bacaan sehingga pembaca bisa lebih lama mengingat setiap gagasan pokok suatu bacaan. Selain itu, menurut hasil penelitian Wright dan Bar, Sartorelli, Swartz, dan Park (Hassoubah, 2004) beberapa cara untuk meningkatkan kemampuan berpikir kritis yaitu membaca secara kritis, meningkatkan daya analisis, kemampuan dalam mengobservasi, kemampuan bertanya, refleksi, dan diskusi. Selanjutnya berdasarkan kajian teoritis, Runisah (2019) menyimpulkan bahwa SQ3R dapat digunakan untuk mengembangkan kemampuan berpikir kritis matematis siswa.

Berbagai kelebihan dapat kita peroleh dari penggunaan SQ3R. Pada tahap survey siswa menentukan konsep penting pada bacaan. Hal ini melatih siswa untuk melakukan analisis. Pada tahap Question siswa membuat pertanyaan yang berkaitan dengan konsep penting yang mereka temukan. Pada tahap read dan recite, siswa ditugaskan membaca ulang kemudian menjawab pertanyaan yang telah mereka buat. Hal tersebut memacu siswa untuk menganalisis keterkaitan antar konsep, kemudian menyimpulkan jawaban yang tepat dari pertanyaan yang dibuatnya. Berkaitan dengan tahapan ini, Slameto (2010) berpendapat bahwa pengertian hanya dapat diperoleh siswa apabila timbul pertanyaan-pertanyaan dan siswa berusaha sendiri menjawabnya.

Pada tahap review, siswa ditugaskan memeriksa jawaban yang telah dibuatnya, kemudian membuat ringkasan dari konsep penting atau konsep utama yang ada dalam bacaan. Pada saat memeriksa jawaban siswa harus memikirkan kembali kebenaran jawaban berdasarkan alasan yang rasional. Kelebihan dari aktivitas meringkas dikemukakan Corner (Meyers, 1986) bahwa kegiatan meringkas merupakan salah satu alat untuk mengajarkan berpikir kritis. 
Berdasarkan kajian tersebut, penggunaan SQ3R memacau siswa untuk melakukan analisis, evaluasi, interpretasi, dan menyimpulkan. Dengan demikian setiap tahap yang ada pada strategi SQ3R memacu siswa untuk berpikir kritis. Hal ini sejalan dengan Facione (Firdaus, dkk. 2015) bahwa konsep paling dasar dari berpikir kritis yaitu kemampuan dalam menginterpretasi, menganalisis, mengevaluasi, menarik kesimpulan, menjelaskan, dan regulasi diri.

Sementara itu pada pembelajaran konvensional, materi diberikan langsung oleh guru, sehingga pembelajaran lebih berpusat pada guru. Dengan demikian siswa kurang dilibatkan secara aktif dalam proses analisis, sintesis dan membangun pengetahuan. Hal ini mengakibatkan kemampuan berpikir krits matematis siswa kurang berkembang secara optimal.

Hasil penelitian ini sejalan dengan hasil studi lainnya. Beberapa studi lain memperlihatkan bahwa terdapat pengaruh positif dari pembelajaran berbasis konstruktivisme terhadap peningkatan kemampuan berpikir kritis matematis siswa (Rohaeti, 2010; Palinussa, 2012; Kurniati, Kusumah, Sabandar, \& Herman, 2015; Yumiati, 2015; Firdaus, dkk. , 2015).

\section{Simpulan}

Berdasarkan hasil penelitian disimpulkan: (1) Peningkatan kemampuan berpikir kritis matematis siswa yang memperoleh pembelajaran dengan menggunakan SQ3R lebih baik daripada siswa yang memperoleh pembelajaran konvensional; 2) Peningkatan kemampuan berpikir kritis siswa kelompok tinggi lebih baik daripada kelompok sedang. Peningkatan kemampuan berpikir kritis siswa kelompok tinggi termasuk kategori tinggi, sedangkan peningkatan kemampuan berpikir kritis siswa kelompok sedang dan rendah ada pada kategori sedang. Meskipun kemampuan berpikir kritis siswa kelompok sedang dan rendah ada pada kategori yang sama, namun peningkatan kemampuan berpikir kritis siswa kelompok sedang lebih baik daripada kelompok rendah.

Dengan demikian berdasarkan hasil penelitian ini guru diharapkan dapat menggunakan SQ3R sebagai alternatif strategi pembelajaran untuk mengembangkan kemampuan berpikir kritis matematis siswa. Selain di 
sekolah, penggunaan strategi ini dapat dijadikan alternatif tugas di rumah untuk mempelajari materi yang akan dipelajari di sekolah.

\section{Daftar Pustaka}

Dahar, R.W. (1989). Teori-Teori Belajar. Jakarta: Erlangga.

Eggen, P \& Kauchak, D (2012). Strategic and Model for Teachers: Teaching Content and Thinking Skills. Boston: Pearson.

Ennis, R.H. (1996). Critical Thinking. United States of America: Prentice-Hall, Inc.

Facione, P.A. (1994). Holistic Critical Thinking Scoring Rubric. Diakses dari www.temple.edu/tlc/resources/handouts/holistic20Critical20 Thinking20Scoring \% 20Rubric.v2.pdf

Firdaus, Kailani, I. Nor, B.B., \& Bakry. (2015). Developing Critical Thinking Skills of Students in Mathematics Learning. Journal of Education and Learning, Vol.9(3), 226-236.

Firmansyah, D.T., Zaenuri, \& Mulyono. (2012). Keefektifan Model Pembelajaran Kooperatif TipE SQ3R terhadap Kemampuan Pemecahan Masalah Siswa SMP Kelas VII. Unnes Journal of Mathematics Vol.1 (2).7-14.

Glazer, E. (2001). Using Web Sources to Promote Critical Thinking in High School Mathematics. [Online]. Diakses dari http://math.unipa.it/ grim/AGlazer79-84.PDF

Hassoubah, Z.I. (2004). Developing Creative \& Critical Thinking Skills. Bandung: Nuansa.

Kurniati, Kusumah, Y.S., Sabandar, J., \& Herman, T. (2015). Mathematical critical thinking skills through contextual teaching and learning. IndoMS-JME, 6(1), 53-62..

Meltzer, D.E. (2002). The Relationship between Mathematics Preparation and Conceptual Learning Gains in Physics: A Posible "Hidden Variable" in Diagnostic Pretest Scores. American Journal of Physics. Diakses dari http : //www.physics.iastate.edu/ per / does /AJP-Dec-2002-Vol.70-12591268.pdf. 
Meyers, C. (1986). Teaching Student to Think Critically. San Francisco: JosseyBass Inc.

Mullis, I.V.S. \& Martin, M.O. (2013). TIMSS 2015 Assessment frameworks.

Martin, M.O (Editor). TIMSS \& PIRLS International Study Center, Lynch School of Education, Boston College and International Association for the Evaluation of Educational Achievement (IEA).

Nizam. (2016). Ringkasan Hasil-Hasil Asesmen: Belajar dari Hasil UN, PISA, TIMSS, INAP. Jakarta: Puspendik Balitbang Kemdikbud

Palinussa, A. (2012). Kemampuan Berpikir Kritis dan Kreatif Matematis, serta Karakter Siswa dalam Pembelajaran Matematika Realistik Berbasis Budaya. Disertasi pada SPS UPI.: tidak diterbitkan

Pujawan, I. G. (2005). Penerapan Model Pembelajaran Kooperatif dengan Metode SQ3R dalam Meningkatkan Aktivitas dan Prestasi Belajar Matematika Siswa SMP. Jurnal Pendidikan dan Pengajaran. Vol. 38(3), 343-358.

Rohaeti, E.E. (2010). Critical and Creative Mathematical Thinking of Junior High School Student. Educationist Journal, Vol 4(2), 99-106.

Runisah. (2012). Kemampuan berpikir kritis matematis siswa SMA (studi pendahuluan).

Runisah. (2019). Penggunaan SQ3R untuk Mengembangkan Kemampuan Berpikir Kritis Matematis. Wacana Didaktika. Vol 7 (1). 12-19.

Slameto. (2010). Belajar dan Faktor-Faktor yang Mempengaruhinya. Jakarta : Rineka Cipta.

Subekti, F.E \& Yanuarto, W.N.(2013). Peningkatan Kemandirian Belajar dan Kemampuan Komunikasi Matematika melalui Pembelajaran SQ3R Khazanah Pendidikan.Vol 2(1). Diakses dari http://jurnalnasional.ump.ac.id/index.php/khazanah/index

Sudrajat (2001) Penerapan SQ3R pada Pembelajaran Tindak Lanjut untuk Peningkatan Kemampuan Komunikasi dalam Matematika Siswa SMU. Tesis pada PPS UPI.: tidak diterbitkan.

Yumiati. (2015). Meningkatkan Kemampuan Berpikir Aljabar, Berpikir Kritis Matematis, dan Self-Regulated Learning Siswa SMP Melalui 
Pembelajaran Core (Connecting, Organizing, Reflecting, Extending). Disertasi. Bandung: Sekolah Pascasarjana Universitas Pendidikan Indonesia 